\title{
Chapter 6 \\ When Policy Meets Practice: A Study \\ of Ethnic Community-Based \\ Organizations for Children and Youth
}

\author{
Marianne Takle and Guro Ødegård
}

\section{Ethnic Community-Based Organizations}

\begin{abstract}
Immigrant youth are rootless. They do not know whether they belong to Norwegian society or if they are a part of something else. This is also my experience. Where do I belong? I find it useful to bring the best from both cultures: maintain roots, acquire resources and integrate into the Norwegian society.
\end{abstract}

This is a quote from a leader of an ethnic community-based organization for children and youth in Norway. He is a young man who came to Norway as a child from Kurdistan, and has lived most of his life in his adopted country. When asked why it was useful to establish special ethnic community-based organizations for children and youth in Norway, he answered that these kids are struggling with the question of belonging and identity. His answer is typical. Many ethnic community leaders working with immigrant youth share his opinion. They bemoan the fact that many of their members seem to forget their cultural heritage. In turn, they encourage cultural and social integration among their members within the organizations, and emphasize simultaneously that this will lead to integration into mainstream Norwegian society.

The Norwegian government has funded several ethnic community-based organizations for children and youth. The leader quoted above represents one of eight such organizations that received support in 2013. The members of these organizations have cultural or ethnic bonds to Sri Lanka, Turkey, Vietnam and Azerbaijan, and two organizations have members from different regions in Kurdistan. While some members are themselves immigrants, others were born in Norway to immigrant parents. The Norwegian state categorizes all of them as children and youth of immigrant background. This classification is congruent with Norwegian citizenship legislation, which considers children born in Norway to

M. Takle $(\bowtie) \cdot$ G. Ødegård

NOVA, Oslo and Akershus University College, Oslo, Norway

e-mail: marianne.takle@nova.hioa.no 
immigrant parents citizens of their ancestral homelands. Children of immigrant parents can apply for Norwegian citizenship, but they must give up their former citizenship, as Norway does not recognize dual citizenship (Takle 2006). This legislation makes it problematic for children born in Norway to escape the migrancy framework the state puts them into. In this chapter, we apply the concept of migrancy as defined in the introduction to this book. We regard migrancy as a socially constructed category, which does not solely reflect the condition of being a migrant, as it is attributed beyond those who have migrated. It is not a place, but a social space (see the introduction to this book written by Seeberg and Goździak).

The migrancy framework is reinforced by the government's funding to ethnic community-based organizations for children and youth. This funding developed within the context of the relationships between civil society (including voluntary organizations), the government and the welfare state in Norway. In Norway, Sweden, Finland, and Denmark there have been interactions between popular movements, civil society, and the state to create and sustain what has been termed the Nordic welfare state model (Kuhnle and Selle 1992). In all Nordic countries, voluntary organizations often have a broad membership base. Participation in voluntary work is generally seen as an integral part of being a member of an organization and organizations are democratically structured (Trähgårdh and Vamstad 2009; Wollebæk and Sivesind 2010). The state's support to ethnic community-based organizations for children and youth is meant to strengthen their civic engagement and political participation in the larger society.

In this chapter, we examine how eight ethnic community-based organizations, which received funding from the state, identify themselves and develop their practice within the framework of the Norwegian tradition of voluntary organization. Our main thesis is that ethnic community-based organizations work to maintain their members' cultural heritage, and may at times contest the Norwegian understanding of voluntary organizations as a stepping-stone to individual participation in the larger society.

We have interviewed eight leaders or representatives of seven of the state-supported organizations. Two of the leaders were born in Norway to immigrant parents, four immigrated when they were between the age of twelve and fourteen years, and one came to Norway at the age of 23. The youth trace their roots to Kurdistan, Vietnam, Azerbaijan, Sri Lanka, and Turkey. In our analyses of these interviews, we find it useful to distinguish between two aspects. First, we examine how these organizations adapt to the category "children and youth of an immigrant background," and how the state defines special schemes for ethnic community-based organizations. We analyze whether they accept or contest the migrancy framework within which they, and their organizations, are placed by the Norwegian state. Secondly, we examine whether these organizations' identities and practices are in line with the government's aim of defining and supporting them as democratic communities. We analyze whether the government and the organizations have diverging goals of establishing special ethnic community-based voluntary organizations for children and youth. 
Moreover, we discuss how the concept of political opportunity structures is developed in academic literature (Jacobs and Tillie 2004; Koopmans et al. 2005; Morales and Giugni 2011) and apply this to youth organizations in the Nordic context. Moreover, we make analytical distinctions between the cultural, social, civic and political dimensions of integration (Eriksen 2010). Although the production of cultural meaning, social interactions, civic engagement and political participation often overlap in practice, these analytical distinctions are useful to overcome a one-sided focus on cultural integration. By using these distinctions, we can examine and compare the similarities and differences in how the Norwegian government and the ethnic CBOs combine these dimensions of integration and thereby contribute to analyses of identity, belonging, and civic and political participation.

Several studies show that young people who have immigrated as children or are born to immigrant parents have different challenges and forms of belonging than their parents and grandparents (Crul and Mollenkopf 2012; Wessendorf 2013; Ødegård et al. 2014). There is, however, lack of knowledge about how these young people organize themselves in migrant organizations. Our study aims to contribute to this debate by analysing ethnic community-based organizations' practices. We examine how they work to encourage members to take part in activities in their ethnic community and in the larger society.

The chapter is divided into five sections. The introduction is followed by a section that examines how government funding for voluntary youth organizations can be understood within the Nordic context. The third part discusses both our contribution to the on-going academic debate on ethnic community-based organizations and the cultural, social, civic and political dimensions of integration. The fourth section covers empirical analysis of the organizations' practice, which we examine in relation to the cultural, social, civic and political dimensions of integration. The chapter concludes that CBOs challenge the government's understanding of integration as processes taking place within nation state boundaries.

\section{Youth Organizations in the Nordic Context}

The concept of the political opportunity structure was developed within the framework of studies of social movements and subsequently adapted to studies of migration (Koopmans and Statham 2000). Examples of such adaptation are the studies conducted by Koopmans et al. (2005) on how the combination of citizenship regimes and cultural group rights affect immigrants' collective actions in several European countries. Studies of political opportunity structures argue that institutions that are created in the receiving countries for immigrants influence the way in which immigrants organize themselves and participate in the larger society through collective action such as immigrant organizations (Odmalm 2004; Togeby 2004; Predelli 2008). 
Several scholars have, in the social capital tradition of Putnam (2000), focused on what role ethnic organizations play in immigrants' civic and political participation (Fennema and Tillie 2001; Jacobs and Tillie 2004). Studies from several European cities find that immigrants' membership in ethnic organizations has a significant bearing on political participation, but also reveals variations between different ethnic groups and different forms of political participation (Jacobs and Tillie 2004; Tillie 2004; Berger et al. 2004; Bay et al. 2010).

More recent studies from several European cities combine these two approaches through analyses of how different compositions of political opportunity structures, organizational membership, and individual factors influence immigrants' political participation (Morales and Giugni 2011). Studies conducted within this analytical framework show that membership in ethnic organizations leads to increased political participation if combined with an open political opportunity structure in the form of multiple group rights (Morales and Pilati 2011, 110; Myrberg and Rogstad 2011, 194; D'Angelo 2015).

These European studies show that both membership in immigrant organizations and the political opportunity structure of the organizations affect the political participation of immigrants and their children. This research, however, does not examine which conditions within the immigrant organizations lead to the members participating in the majority society's civic and political activities. Taking these findings, which are mostly based on quantitative studies, as the point of departure gives rise to a need to conduct a qualitative study of what the immigrant organizations do to promote civic engagement and political participation among members.

Nordic research shows an increasing connection between the state's support of civil society institutions and greater involvement of civil society organizations to promote integration of ethnic minority groups into majority society (Pyykkonen 2007; Bengtsson 2010; Kugelberg 2011; Agergaard and Michelsen la Cour 2012). In Norway, two national institutions register voluntary organizations for youth. One is Fordelingsutvalget, the Distributive Committee, which is an administrative body under the Ministry of Children, Equality and Social Inclusion. The committee's main task is to distribute grants to Norwegian voluntary children and youth organizations. In order to receive financial support, the state requires that the youth organizations are both membership-based and have an internal democratic structure. These requirements can be understood within the framework of central characteristics of the voluntary sector in the Nordic countries.

The other national institution is the Norwegian Children and Youth Council, Landsrådet for Norges barne- og ungdomsorganizasjoner (LNU). LNU is an umbrella organization for approximately ninety non-governmental organizations for all children and youth in Norway. This includes a variety of organizations, such as religious, political, cultural and leisure organizations. LNU is an independent and democratic organization, which both represents the member organizations' common interest in relation to political authorities and offers different types of services (such as seminars, meetings, international networking etc.) for its member organizations. 
LNU — as a body for youth organizations' interests - can be understood as integrated in the wider Nordic tradition of voluntary organization. As mentioned above, central characteristics of this tradition is that voluntary organizations often have a broad membership base, participation in voluntary work is generally seen as an integral part of being a member of an organization and organizations are democratically structured (Trähgårdh and Vamstad 2009; Wollebæk and Sivesind 2010). The normative ideal is that organizations should be democratically organized in such a way that their actions reflect their members' preferences (Lorentzen 2004, 31). Groups are seen as a collective of individuals, and democratic procedures within groups give all members an opportunity to participate. Participation in organizations socializes each individual member into democratic values and gives them training in practical democracy.

The Nordic tradition of voluntary organizations is also characterized as a people's movement model, and in the Norwegian context, people's movements have brought broad groups from all over the country into the public domain since the latter half of the 19th century (Østerud et al. 2003). Historically, the aim has been to create political weight and legitimacy through mass membership, built on a broad social mobilization. The Norwegian emphasis on democracy can partly be explained by the fact that civil organizations were established in the same period as national independence. Nineteenth century mainstream popular movements followed the same organizational structure as the political parties. They have been characterized by a hierarchical organization, where local organizations are linked together in regional and national organizations (Østerud et al. 2003). People's movements provided local interest in the political centre, and in many cases acted as counter-cultures to the majority culture.

In line with the Nordic tradition, hierarchical and rule-based organizations are established outside the state administration. They function as an alternative political channel, and a form of political influence outside the party system and the election channel (Rokkan 1966). The voluntary organizations function as a parallel bureaucratic structure, but there are also huge overlapping zones between voluntary organizations and state administration.

Voluntary organizations are crucial to Norwegian democratic culture and identity (Lorentzen 2004). The idea is that voluntary organizations can be places where members learn democratic values in practice - both civic and political. They are socialized in democratic decision-making procedures even when the organizations do not aim to have political influence, but are rather engaged in civic, cultural and social activities. Hence, within the Nordic tradition, the distinction between civic and political engagement often becomes blurred. Both types of engagements imply relations between individuals or groups and public institutions. This can include civic engagement in public institutions and political participation such as voting in elections or running for elected office.

Although scholars find that there has been a gradual transition in the Norwegian voluntary sector away from the people's movement model towards philanthropy, they simultaneously conclude that as a normative ideal, the membership-based, 
democratic, and hierarchical model of voluntary organizations has vitality (Wollebæk and Sivesind 2010; Folkestad et al. 2015).

Studies from the Nordic countries show that central elements of the Nordic tradition of organizing the voluntary sector are applied to ethnic community-based organizations (Borevi 2004; Pyykkonen 2007; Predelli 2008; Hagelund and Loga 2009; Bay et al. 2010; Ødegård 2010; Kugelberg 2011; Myrberg and Rogstad 2011; Takle 2014). When we place the ethnic community-based organizations for children and youth in our study in the wider context of the Nordic tradition of civil society, we recognize these central characteristics. The government formulates the democratic ideal by referring explicitly to this tradition:

Meanwhile, the government is concerned that the voluntary organizations, including immigrant organizations, follow democratic principles. By allocating support to organizations it has traditionally been emphasized that the organizations must have a democratically elected leadership and an elected board. This also applies to immigrant organizations (White Paper No. 39 2006-2007, 62).

It thus appears that the policy is based on the belief that identities are important, but that identities linked to other ethnic or national groups shall not influence majority institutions. Analysing White papers from the early 2000s, Gressgård (2005) finds a general recognition of cultural differences, but in practice these policies are tied to the individual. The Norwegian government's respect for immigrants and their descendants' culture as groups is limited to some areas and rather instrumental. The government sees the ethnic and national groups as places for cultural and social integration in small communities. The idea is that such integration among equals will lead to increased participation in the wider society:

Immigrant organizations can function as a stepping stone for contact with other inhabitants and participation in other arenas, and in this way strengthen immigrants' belonging to the larger society (White Paper No. 6 2012-2013, 126).

In accordance with the Nordic tradition of voluntary organization, ethnic community-based organizations engaged in cultural and social activities can be places where members learn democratic values in practice. The government's rationale for seeing the CBOs as a stepping-stone to wider civic and political engagement is the belief in this Nordic tradition where the voluntary organizations are expected to contribute to democratic education (White Paper No. 6 2012-2013, 123). There is an ambiguity in Norwegian government policy in this field: The aim of supporting ethnic community-based organizations is not to strengthen the group as such, but rather to use the organizations as an arena to nudge individual children and youth towards civic and political participation in the Norwegian mainstream society. According to Berkaak (2012) the Norwegian policy is both ambiguous and vague, and when this policy is gradually implemented it might lead to measures that counteract each other in practice. 


\section{The Concept of Integration}

There is an on-going academic debate on whether ethnic community-based organizations lead to integration of their members in the host society or to increased segregation among minorities (Jacobs and Tillie 2004; Portes et al. 2007; Yurdakul 2009; Bay et al. 2010; Glick Schiller 2010; Faist 2010; Morales and Pilati 2011). Several studies show that most ethnic CBOs are both preserving the cultural heritage of their country of origin and facilitating migrants' integration into the country of settlement (Amelina and Faist 2008, 2012; Handy and Greenspan 2009; Glick Schiller 2010). This can be contrasted with countries with a long history of immigration such as Canada (Bauder 2011). In the Norwegian context Ødegård et al. (2014) show that ethnic community-based organizations and networks have different purposes for different groups. For newcomers, the organizations play a crucial role as an arena for social contact between different waves of immigrants. The organizations also operate as a forum for disseminating essential information about rights, eligibility for welfare and access to education and childcare. The organizations serve as meeting places for young people who position themselves in relation to dual identities, and for those struggling with balancing cultural practices rooted in the country of origin and the country of settlement. For children born and raised in Norway, these networks also serve as an arena to learn their heritage language and traditional cultural expressions. Finally, ethnic community-based organizations contribute to the political mobilization of networks of immigrants in a Norwegian context (see also Bjørklund and Bergh 2013; Takle 2014).

Refuting the assumption that ethnic community-based organizations are a hindrance to successful immigrant integration in their countries of settlement, studies have shown that ethnic CBO's transnational activity and their members' integration in their settlement society are not at odds with each other (Amelina and Faist 2008; Horst et al. 2010). Amelina and Faist (2008) conclude in their study of Turkish organizations in Germany that religious, economic, and political organizations in Germany combine their transnational ties with German integration pressure, but in various ways. Such findings are of special relevance for Norwegian ethnic CBOs for youth as members of the organizations included in this study have lived most or all of their lives in Norway.

\section{The Cultural, Social and Civic/Political Dimensions of Integration}

Inspired by Eriksen (2010, 69-109), we define the cultural, social, civic and political dimensions of integration in the following way: (1) The cultural dimension of integration refers to understandings of implicit and explicit communication, and this requires common language, codes, and symbols. These are often based on common historical experiences. (2) The social dimension of integration refers to 
persons, network and feelings of belonging. This implies interactions between friends and colleagues, and is often based on face-to-face contact. (3) Both the civic and the political dimensions of integration refer to individuals' relations to the system such as bureaucratic and democratic institutions. They mainly imply relations between individuals or groups and public institutions. Such relations can both include civic engagement in public institutions and political participation such as voting in elections or running for election. Although the production of cultural meaning and social interaction mostly overlap in practice, we can imagine situations where individuals understand the world in a similar way, and understand each other, without having any interactions. This is often the case within abstract national frameworks (Anderson 1991).

It is, however, crucial to distinguish between different levels of integration. Integration in the larger mainstream society refers to the relationship between individuals, or groups, and public institutions. This is an abstract relationship, which also has cultural aspects (Takle 2014). In contrast, membership in an ethnic community-based group refers to small-scale integration, in which people meet each other face-to-face. Both are forms of formal belonging, which stand in contrast with informal networks and close friends.

The civic and political dimension of integration refers to the macro level, such as public institutions and their stability and reproduction. These are public institutions such as police, hospitals, schools and public administration. The social dimension of integration can both take place within public institutions and at the micro level through kinship groups and friends. While the civic and political dimension of integration refers to how public institutions work, the social dimension refers to the characteristics of personal interactions within such institutions. There can also be distrustful relations in cases where public institutions such as the police and public administration do not work. In contrast, public institutions might function in situations where there are weak social networks and a lack of feelings of belonging. Moreover, if the social networks and feelings of belonging are only related to separate groups and there are no common institutions that mediate between personal networks and groups, the society becomes fragmented. The outcome might result in lack of trust in abstract systems (Eriksen 2010).

The three dimensions may take various forms in relation to the feeling of belonging of an ethnic community-based group and of the larger society. Young people can be integrated in the country they live in through friends, school, work, and in relation to politics and public administration. Simultaneously, their cultural and social dimensions of integration can be bound to ethnic communities. Moreover, ethnic community-based groups are often oriented towards their members' countries of origin and tie their identity to these homelands. Although the organizations' members do not necessarily travel between countries, the organizations might structure their cultural, social, civic and political dimensions of integration in multiple nation-state contexts (Amelina and Faist 2008). Transnational ties might be reflected in how ethnic community-based organizations aim to pursue the identity of their members' country of origin within their country 
of settlement, and thereby challenge an idea of integration as processes taking place within nation-state boundaries.

\section{Eight Ethnic Community-Based Organizations for Children and Youth}

There are several local ethnic CBOs for youth in Norway. This study covers all eight ethnic CBOs for children and youth that received funding from the Norwegian state in 2013. To receive such funding, the organization must have a minimum of 100 paying members below the age of 26 , and they must have local branches in two municipalities in Norway. Just to compare: regular youth organizations - with no recruitment limitations such as ethnic community-based organizations (for example leisure- and political organizations) - need 700 paying members below the age of 26 , and local branches in five municipalities.

We have selected well-established organizations that are relatively robust and provide activities for large groups of youth. Students' and sports organizations are not included in this support scheme, and are therefore excluded from our analysis. None of the ethnic CBOs that receive this funding works to promote religion. Moreover, the selected organizations are formally independent from their parent organizations. $^{1}$

The selected organizations reported mainly to have members from one ethnic community. The organizations represent children and youth tracing their roots to Kurdistan, Vietnam, Azerbaijan, Sri Lanka, and Turkey. These countries do not, however, reflect the countries of origin of most immigrants in Norway. In 2014, there were 663,110 immigrants in Norway, and 126,075 children of two immigrant parents born in Norway. Around $12 \%$ of the population are immigrants, and around $2 \%$ are children of immigrants. While the largest national groups of immigrants come from Poland, Sweden, and Lithuania, the largest national groups of Norwegian-born children of immigrant parents come from Pakistan, Somalia, and Iraq (SSB 2014). We can only speculate about the reasons for the divergence between the ethnic community-based organizations for children and youth that receive funding, and the largest immigrant groups. All ethnic CBOs can apply, and most of those who apply receive funding. While there are no formal restrictions preventing various groups from applying, there might be informal reasons not to apply. We have, however, concentrated on the eight organizations that received government support in 2013.

\footnotetext{
${ }^{1}$ Children- and youth organizations must be defined as self-governed associations to receive funding. Accordingly, the government requires that they have an internal democratic structure which ensures the members right to express themselves and be heard through formal annual meetings. The rights for individual members are regulated by the organization's statutes. Decisions made in an organization's formal meetings, cannot be overruled by any other organizations.
} 
The methodology is based on document analysis and interviews. We have studied public documents that give criteria for funding to children and youth organizations with members from various regions in Norway. We have visited the organizations' webpages and their profiles on Facebook, and we have studied their statutes. Moreover, we have conducted interviews with leaders of seven organizations. We approached the leaders by sending emails and text messages. Several of the leaders do not live in Oslo. None of them were employed by the organization they lead; all were fully engaged in work or studies. Their contribution as leaders was voluntary and they performed their duties in their spare time. Four interviews were conducted in the organizations' offices, while the remaining three were conducted at our research institute. These were semi-structured interviews; we followed an interview guide where questions and topics we wanted to cover were recorded. We started each interview by asking personal questions about the leaders' motivation for using their spare time to work for the organization. We then followed up with questions related to the organizations' aim, main activities, and the members' engagement. Each interview was concluded with a question about the organizations' future. While we used a common interview guide for each conversation, follow-up questions were also discussed when appropriate. While one researcher asked the questions, the other took notes.

\section{The Organizations' Practice}

The question examined in this section is how the ethnic community-based organizations for children and youth combine cultural and social activities in ethnic CBOs with civic and political integration in the mainstream society. As mentioned in the introduction, we both examine how these organizations adapt to the migrancy framework they are put in by the state, and how they define the aim of establishing special ethnic CBOs for children and youth.

We have to bear in mind that these are relatively small organizations without any full-time employees. Four of them have accountants in part-time positions, but volunteers carry out the daily work. While the registered members are below the age of 26, some organizations also have supporting members above this age. The largest organization has 1,969 Tamil members who have parents who immigrated to Norway from Sri Lanka, or were born to immigrant parents. The organization has fourteen local branches, and is also the oldest organization, founded in 1992. Two organizations have a total of 327 and 379 members. These are immigrants from Vietnam or children of Vietnamese immigrants. Although these have organized activities over several years, they have only received funding for the last few years. One organization, founded in 2006, has members originating in Azerbaijan. This organization has 209 members, and two local branches. These organizations mainly arrange language courses and cultural activities to maintain the cultural heritage from their ancestral country. 
There are four small organizations with fewer than 209 members. Two of these are Kurdish organizations, which are linked to mother organizations in Kurdistanone in Koye and one in East-Kurdistan. Furthermore, there are two organizations for youth of Turkish origin. One was founded in 2001 and aims to promote cultural, academic, and social activities. For several years, this organization served as an important channel for youth to reach the attention of political authorities in Norway. In 2014, the organization dissolved when the founder quit her unpaid job as General Secretary in the organization. In 2005, the other organization for youth of Turkish origin was founded (Centre for Multicultural Youth). All members speak Turkish and focus on arranging social and cultural activities. All organizations are non-profit, non-religious and non-political voluntary organizations, in the sense that they do not support a specific political party, neither in Norway nor in Turkey.

The leaders of the organizations are resourceful individuals, who have crucial influence on the organizations' ideas and practice. They describe how they are integrated in the larger society in relation to cultural, social, and political dimensions. All leaders have higher education. They have all been active in voluntary work since they were children. Currently, they each devote the bulk of their voluntary efforts to the organization they are leading.

\section{Migrancy Framework}

While six leaders had immigrated to Norway and two were born in Norway to immigrant parents, all informants emphasized how their parents' migration histories define their own cultural heritage. They all referred to strong relationships with their parents. All leaders emphasized that it is important that the members' parents have knowledge of the organizations' social network and cultural activities. This makes it easier for the youth to participate in the organizations. Nevertheless, the organizations have diverging approaches to intergenerational relations. Four leaders explained that parents encourage their children to participate in the activities of the organizations because they want their children to maintain their ethnic identity. Parents feel that the organizations are safe spaces for their children. However, four other leaders emphasized that parents should not attend activities organized by the group. One of them even emphasized that the establishment of a self-governed youth organization was in part a rebellion against sceptical expressions in the immigrant society regarding the organization's non-religious profile and that it included all young people of diverging cultural, religious or ethnic family background.

All leaders called themselves immigrant children and youth, or children and youth from an immigrant background. None of them made distinctions between persons who have immigrated and Norwegian-born children with immigrant parents. We did not, however, ask whether they have applied for Norwegian citizenship, as we were mainly interested in the organizations. As we have seen, the Norwegian citizenship policy forms the legal basis for the migrancy framework, in 
which the state situates the children and youth. The migrancy framework is reinforced by the special support schemes for ethnic CBOs. Altogether, the definitions and use of these categories are crucial for how the children and youth understand their position in the Norwegian society.

One way of understanding why the leaders never questioned the migrancy framework they were placed into might be that they adapt to the funding schemes. No one criticized these schemes. The existence of a special funding system for ethnic community-based organizations is encouraging children and youth to organize themselves as ethnic communities and establish such organizations. The organizations' adaptation to the migrancy framework might also be a question of selection. Those persons who have strong connections to their ethnic community and immigration histories might be more prone to apply for such funding. Although all leaders told us that their ideas and activities are based on their own experiences, they also emphasized how their parents' migration histories define their own cultural heritage. The question is how this understanding defines the organizations' identity and practice, and whether the organizations maintain their members' lives in migrancy.

\section{Cultural Maintenance}

The point of departure for the organizations' ideas and practices is that their members are culturally and socially integrated in Norwegian society. They know the Norwegian language, codes, and symbols. Moreover, they have personal interactions and networks within the framework of public institutions at school and at work.

In contrast, the cultural and social dimensions of integration within their ethnic community are weak, and according to the leader quoted in the introduction, this makes immigrant youth and children of immigrant parents rootless. All organizations emphasized that it is crucial that the youth do not forget "their own culture." Four leaders emphasized that young people seem to forget their language and cultural heritage. One leader emphasized that they cannot lose these forms of belonging:

We have tried to get as many youth as possible together so that they do not forget their background and culture. We have seen that when they come to Norway they forget their background. We want the youth to bring with them their own culture and simultaneously learn the Norwegian culture.

The leaders' central argument is that it is not possible to choose between these two forms of belonging. They do not perceive this as a question of either/or but rather of both. Their aim is to develop robust hyphenated identities. All leaders argued that their members' challenges are related to how they combine both forms of belonging, as one leader put it: 
We wish every individual to mix two cultures. This is difficult for the first generation of immigrants, while the second generation have Norwegian education and live with such a mix. The third generation is mainly Norwegian.

The leaders aim to use the organizations as a mean to build young peoples' identity, and one leader said:

We must build identities where we combine two cultures so that each young individual can be independent in various situations. This will strengthen the youth as individuals and give them more possibilities.

All leaders emphasized explicitly, as we have seen in different words, that the building of identities is a way to broaden the young peoples' cultural repertoire. Two leaders referred to the problematic age between thirteen and eighteen, and how young people tend to form their identity during this developmental period. Both of them referred to their own experiences and how important it was for them to meet young people with a similar cultural heritage.

The organizations' practices follow similar patterns of activities. All organizations offer language courses to their members. Four leaders indicated that their members attend Norwegian schools and have mastered the Norwegian language, but have limited knowledge of their heritage languages and need to learn them in order to be able to communicate with community members and understand their culture of origin. This focus on the cultural dimension of integration within the ethnic community is reflected in the organizations' main activities: cultural pursuits such as dancing, music festivals, and sport activities.

\section{Social Network for People with the Same Cultural Heritage}

The organizations also arrange social activities for their members, such as barbecues, trips to country cottages, and mountain walking. These activities aim to offer places where people with heritage from the same country can get together and integrate socially. One of the leaders articulated this goal as follows:

I have a personal motive with this work. I can see what they are struggling with. We can get the youth off the streets; get them socially together, and encourage them to study and to integrate more. I was the first generation of youth from our group. When I came to the university, I did not know what to study. I have gone through a lot, and I have learned much. I have seen many young people with the same problems as I had. I can help them.

His own experiences are crucial for how the organization combines various forms of social activities. Another leader linked his personal motive to voluntary work as a duty:

I see it as a duty to participate in voluntary work. Several people have been helping me.

Without them, I would not have been the person I am now. 
They described how their organizations are dependent on their work and engagement. One of the leaders referred to how the social network is an intrinsic part of his work:

Much of the organization's operations are dependent on me. To take over after me would imply a huge responsibility and also a great pressure. I know the work, and I deliver work of high quality. I know everyone, and people know who I am.

While informal social networks are crucial for all leaders, the formal organizations offer an arena where the leaders can get in contact with and encourage youth to maintain their ethnic identity and foster participation in the larger society. All leaders described their organizations as places where young people can meet and recognize the value of knowing other people who navigate between two cultures. Most leaders referred to how this awareness can lead to increased self-confidence, and one of them argued:

If you do not have an identity you cannot behave as an independent individual. You must be able to combine in relation to what you want, and how you want to organize your everyday life. All this is dependent on who you want to be, and that decides what parts of the culture you take with you.

The goal of several organizations is to build social networks based on various combinations of membership in an ethnic community-based group and civic and political participation in the larger society. This will, according to the leaders, give the young people a broad cultural competence. As one of the leader said:

\footnotetext{
If young people want to succeed, they have to know themselves. Young people are standing in the middle of two cultures. There are negative parts of both cultures, but we must take with us the positive parts. It is extremely useful to have knowledge of two cultures. I use this at work every day.
}

\section{Civic and Political Engagement}

Most organizations arrange seminars where they inform their members about the Norwegian education system and about how the political system works. These are efforts to promote the civic and political dimension of integration in the larger society, and are often combined with social activities. As several leaders said, to encourage members to participate in different events, the organizations must combine information about public institutions with fun and appropriate activities. Nevertheless, most of the leaders emphasized their members' knowledge about democratic procedures. Four leaders highlighted internal democratic structures in the organizations and how the group of leaders changes every second or third year, after national meetings. Three of the leaders were central in the establishment of the organizations, and they have been leading the organizations since then. They did not refer to internal democratic elections, but to receive funding they also must follow democratic procedures. 
Most organizations arrange seminars where they inform about the history and political situation in the country they or their parents emigrated from. The aim is that members should have knowledge about the political conflicts in their ancestral countries and thereby the reason why they have emigrated to Norway. Although this is related to the political system in these countries, none of the organizations state that they work with political issues. Three leaders emphasized, however, that their organization's existence is political. These three organizations have members with bonds to Kurdistan and Sri Lanka. All three organizations' practices are related to teaching young people languages, cultural, and historical traditions, which political regimes around Kurdistan and Sri Lanka aim to eliminate. These are cultural traditions which are political because they are perceived as a threat to political regimes. This type of political conflict is a part of these CBOs members' daily life and define these groups' understanding of themselves. One leader says that:

In our enemies' opinion we will always be political, this is a part of our existence.

All organizations are transnational in the sense that they aim to maintain the language and culture of the countries of origin and combine this with civic and political participation in the Norwegian society. However, the organizations are mainly dedicated to improving their members living conditions in Norway. Although they function as bridge between cultures, only one organization defines itself as a bridge between two countries. All organizations have some loose cooperation with sister organizations in the Nordic countries and most leaders aim to increase this cooperation. One organization has close relations to a mother organization in Kurdistan, and members of this organization travel between these countries. Another organization has applied for funding from Norwegian authorities to be able to send some of their members to their ancestral homelands. Three organizations have sent funding to other countries, while one organization has received funding from another country to promote this country's culture in Norway. While this indicates that the ethnic community-based organizations for children and youth have a modest interest in civic and political integration, they fulfil the government's formal requirements to get funding. They do not have to be politically active to fulfil the government's aim to increase democratic participation.

\section{Cultural Heritage Preservation and Democratic Participation}

This study shows how the Norwegian policy on ethnic CBOs for children and youth meets practice. The political opportunity structures show that the government has an ambiguous policy. The aim in supporting these organizations is not to strengthen their ethnic community-based identity, but rather to encourage cultural and social activities. The organizations are seen as places where members learn democratic 
values in practice and thus function as a stepping-stone to individual democratic participation in the larger society. This confirms how previous studies have argued that Norwegian policy is based on vague and ambiguous policy and when this policy is gradually implemented - after several years with immigration - it will lead to measures that counteract each other in practice (Berkaak 2012).

Both the government and the ethnic CBOs for children and youth perceive the organizations as an arena for cultural and social activities among young immigrants or Norwegian-born children of immigrants. Both assume that the organizations can help their members to combine membership in an ethnic community-based group with participation in the larger Norwegian society. They differ, however, in how the organizations should carry out this dual mission.

While the organizations' ideas and activities are based on their members' own experiences, the leaders also emphasized how their parents' migration histories are crucial for their members' cultural heritage. They did not contest being defined and supported in relation to their own, and their parents', immigration history. This can be interpreted as an instrumental adaptation to the Norwegian government's funding system. However, some seem to have internalized the migrancy status inscribed on them. They, thereby, not only maintain the state's migrancy framework, but also consolidate young people's lives in migrancy.

However, they refuse to perceive the activities in the organizations as only a step on their way to individual participation in the larger society. In contrast, the ethnic community-based organizations define their main goal as encouraging young people to maintain the cultural heritage and socialize with people who have similar immigration histories. The organizations emphasize that immigrant youth or children of immigrants seem to forget their common immigration roots and culture. They also forget their language, codes and symbols. The organizations' aim is to maintain their cultural heritage as a way of strengthening their members' identity as Norwegians with cultural heritage from another countries or regions.

In this way, the Norwegian policy on ethnic CBOs for children and youth meets practice. The government's political opportunity structures define an ambiguous policy and leaves it open for children and youth to determine the content. When the organizations' cultural and social dimensions of integration are defined in relation to their membership in an ethnic community, it is crucial that these languages, codes, symbols and social network are transnational. The civic and political dimension of integration is based on the cultural and social dimension, and become visible in their transnational networks. By combining two cultures and two kinds of social networks in relation to two countries, the ethnic CBOs for children and youth work to broaden their members' cultural repertoires and thereby shape new hybrid and transnational identities that also include an identity as political actors. This challenges the Norwegian government's idea of perceiving ethnic CBOs as stepping-stones to individual participation in the Norwegian society. 


\section{References}

Agergaard, S., \& Michelsen la Cour, A. (2012). Governing integration through sports. Nordic Journal of Migration Research, 2(1), 26-34.

Anderson, B. (1991). Imagined communities. Reflections on the origin and spread of nationalism. London, New York: Verso.

Amelina, A., \& Faist, T. (2008). Turkish migrant associations in Germany: Between integration pressure and transnational linkages. Revue européenne des migrations internationales, 24(2), 91-120.

Amelina, A., \& Faist, T. (2012). De-naturalization the national in research methodologies: Key concepts of transnational studies in migration. Ethnic and Racial Studies, 35(10), 1707-1724.

Bauder, H. (2011). Immigration dialectic: Imagining community, economy and nation. Toronto: University of Toronto Press.

Bay, A. H., Hagelund, A., \& Finseraas, H. (2010). Civil society and political integration of immigrants in Norway. In B. Bengtsson, P. Strömblad, \& A. H. Bay (Eds.), Diversity, inclusion and citizenship in scandinavia (pp. 295-323). Newcastle upon Tyne: Cambridge Scholars Publishing.

Bengtsson, B. (2010). Political opportunity structure and ethnic organization: How political, what opportunities, which structures? In B. Bengtsson, P. Strömblad, \& A. H. Bay (Eds.), Diversity, inclusion and citizenship in Scandinavia (pp. 241-269). Newcastle upon Tyne: Cambridge Scholars Publishing.

Berger, M., et al. (2004). Political integration by a detour? Ethnic communities and social capital of migrants in Berlin. Journal of Ethnic and Migration Studies, 30(3), 491-507.

Berkaak, O. A. (2012). De andres mange ansikter-Mangfold i tanker, ord og gjerninger. Norsk antropologisk tidsskrift, 23(1), 66-76.

Bjørklund, T. \& Bergh, J. (2013). Minoritetsbefolkningens møte med det politiske Norge. Partivalg, valgdeltakelse, representasjon. Oslo: Cappelen Damm Akademisk.

Borevi, K. (2004). Den svenske diskursen om staten, integrationen och föreningslivet. In B. Bengtsson (Ed.), Föreningsliv, makt och integration. (pp. 31-65). Rapport från Integrationspolitiska maktutredningens forskningsprogram. Rapport 49.

Crul, M., \& Mollenkopf, J. (2012). The changing face of world cities. Young adult children of immigrants in Europe and the United States. New York: Russel Sage Foundation.

D’Angelo, A. (2015). Migrant organizations: Embodied community capital. In L. Ryan, U. Erel, \& A. D'Angelo (Eds.), Migrant capital. Networks, identities and strategies (pp. 83-101). London: Palgrave Macmillan.

Eriksen, T. H. (2010). Samfunn. Oslo: Universitetsforlaget.

Faist, T. (2010). Diaspora and transnationalism: What kind of dance partners? In R. Bauböck, \& T. Faist (Eds.), Diaspora and transnationalism. concepts, theories and methods (pp. 9-35). Amsterdam: Amsterdam University Press.

Fennema, M., \& Tillie, J. (2001). Civic community, political participation and political trust of ethnic groups. Connections, 24(1), 26-41.

Folkestad, B., et al. (2015). Frivillig innsats i Noreg 1998-2014. Kva kjenneteikner dei frivillig og kva har endra seg? Oslo: Senter for forskning på sivilsamfunn og frivillig sektor.

Glick Schiller, N. (2010). Long distance nationalism and peripatetic patriots. In B. Riccio \& C. Brambilla (Eds.), Transnational migration, cosmopolitanism and dis-located borders (pp. 27 53). Luglio: Guaraldi.

Gressgård, R. (2005). Hva mener regjeringen med flerkulturelt mangfold? Nytt Norsk Tidsskrift, 22 (1), 72-79.

Hagelund A. \& Loga J. (2009). Frivillighet, innvandring, integrasjon. En kunnskapsoversikt. ISF Report 1.

Handy, F., \& Greenspan, I. (2009). Immigrant volunteering: A stepping stone to integration? Nonprofit and Voluntary Sector Quarterly, 38(6), 956-982. 
Horst, C., Carling, J., \& Ezzati, R. (2010). Immigration to Norway from Bangaldesh, Brazil, Egypt, India. Morocco and Ukraine. PRIO Paper. Oslo: Peace Research Institute Oslo.

Jacobs, D., \& Tillie, J. (2004). Introduction: Social capital and political integration of migrants. Journal of Ethnic and Migration Studies, 30(3), 419-427.

Kuhnle, S \& Selle, P (1992). Government and voluntary organizations: A relational perspective. In S. Kuhnle \& P. Selle (Eds.), Government and voluntary organizations, Aldershot, Hampshire, England: Avebury, Ashgate Publishing.

Kugelberg, C. (2011). Integration policy and ethnic minority associations. In C. Shore, et al. (Eds.), Policy worlds. anthropology and analysis of contemporary power (pp. 264-282). New York: Berghahn Books.

Koopmans, R., \& Statham, P. (2000). Migration and ethnic relations as a field of political contention: An opportunity structure approach. In R. Koopmans \& P. Statham (Eds.), Challenging immigration and ethnic relations politics: Comparative European perspectives (pp. 13-17). Oxford: Oxford University Press.

Koopmans, R., et al. (2005). Contested citizenship: Immigration and ethnic relations politics in Europe. Minnesota: Minnesota University Press.

Lorentzen, H. (2004). Fellesskapets fundament—sivilsamfunnet og individualismen. Oslo: Pax.

Morales, L. \& Giugni, M. (2011). Social capital, political participation and migration in Europe: Making Multicultural democracy work? Basingstoke: Palgrave.

Morales, L., \& Pilati, K. (2011). The role of social capital in migrants' engagement in local politics in European cities. In L. Morales \& M. Giugni (Eds.), Social capital, political participation and migration in Europe: Making multicultural democracy work? (pp. 87-115). Basingstoke: Palgrave.

Myrberg, G., \& Rogstad, J. (2011). Patterns of participation: engagement among ethnic minorities and the native population in Oslo and Stockholm. In L. Morales \& M. Giugni (Eds.), Social capital, political participation and migration in Europe: Making multicultural democracy work? (pp. 172-198). Basingstoke: Palgrave.

Odmalm, P. (2004). Civil society, migrant organizations and political parties: Theoretical linkages and applications to the Swedish context. Journal of Ethnic and Migration Studies, 30(3), 471489.

Ødegård, G. (2010). Foreningsliv i et flerkulturelt lokalsamfunn. En studie om integrasjon og sosial kapital, ISF Rapport 6, Oslo.

Ødegård, G., et al. (2014). Fellesskap og forskjellighet. Integrasjon og nettverksbygging $i$ flerkulturelle lokalsamfunn. Oslo: Abstrakt forlag.

Østerud, Ø., et al. (2003). Makten og demokratiet. En sluttbok fra Makt- og demokratiutredningen. Oslo: Gyldendal.

Predelli, L. N. (2008). Political and cultural ethnic mobilization: The role of immigrant associations in Norway. Journal of Ethnic and Migration Studies., 34(6), 935-954.

Putnam, R. D. (2000). Bowling alone: The collapse and revival of American community. New York: Simon \& Schuster.

Portes, et al. (2007). Immigrant transnational organizations and development: A comparative study. International Migration Review, 41(1), 242-281.

Pyykkonen, M. (2007). Integrating governmentality: Administrative expectations for immigrant associations in Finland. Alternatives, 32(1), 197-224.

Rokkan, S. (1966). Norway: Numerical democracy and corporate pluralism. In R. A. Dahl (Ed.), Political oppositions in western democracies. New Haven: Yale University Press.

SSB. (2014). Statistisk sentralbyrå. Statistics Norway. Retrieved March 3, 2015 from http://ssb.no/ innvbef/.

Takle, M. (2006). Statsborgerskapsdebatt i Norge og Tyskland. Internasjonal Politikk, 64(2), 199213.

Takle, M. (2014). Immigrant organizations as schools of bureaucracy. Ethnicities, 15(1), 92-111.

Tillie, J. (2004). Social capital of organizations and their members: Explaining the political integration of immigrants in Amsterdam. Journal of Ethnic and Migration Studies, 30(3), 529 541. 
Togeby, L. (2004). It depends... How organizational participation affects political participation and social trust among second-generation immigrants in Denmark. Journal of Ethnic and Migration Studies, 30(3), 509-528.

Trähgårdh, L., \& Vamstad, J. (2009). Att ge eller att beskattas. Avdragsrätt för gåvor till ideell verksamhet $i$ Sverige och andra länder. Stockholm: Tankesmedjan för det civila samhället.

Wessendorf, S. (2013). Second-generation transnationalism and roots migration. London: Ashgate.

White Paper No. 39. (2006-2007). Norwegian Ministry of Culture.

White paper No. 6. (2012-2013). Ministry of Children, Equality and Social Inclusion.

Wollebæk, D. \& Sivesind, K. H. (2010). Fra folkebevegelse til filantropi? Frivillig innsats i Norge 1997-2009. Oslo: ISF Report 3.

Yurdakul, G. (2009). From guest workers into muslims: The transformation of Turkish immigrant associations in Germany. Newcastle, UK: Cambridge Scholars Press.

Open Access This chapter is licensed under the terms of the Creative Commons Attribution-NonCommercial 2.5 International License (http://creativecommons.org/licenses/by-nc/ $2.5 /$ ), which permits any noncommercial use, sharing, adaptation, distribution and reproduction in any medium or format, as long as you give appropriate credit to the original author(s) and the source, provide a link to the Creative Commons license and indicate if changes were made.

The images or other third party material in this chapter are included in the book's Creative Commons license, unless indicated otherwise in a credit line to the material. If material is not included in the book's Creative Commons license and your intended use is not permitted by statutory regulation or exceeds the permitted use, you will need to obtain permission directly from the copyright holder.

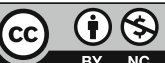

